\title{
Weight-to-weight conversion factors for marine benthic macroinvertebrates
}

\author{
Anthony Ricciardi*, Edwin Bourget \\ GIROQ, Département de Biologie, Université Laval, Ste-Foy, Québec G1K 7P4, Canada
}

\begin{abstract}
The measurement of macroinvertebrate biomass involves time-consuming procedures and the destruction of specimens. However, from simple wet weight (WW) measurements, conversion factors provide rapid estimates of ash-free dry weight (AFDW) that facilitate large-scale comparisons of secondary production and energy flow. From a compilation of published and unpublished data, we have calculated general conversion factors for 28 taxonomic groups of benthic marine macroinvertebrates, as well as for several species of commercial importance. Despite methodological and regional differences among studies, narrow confidence limits surrounded mean values for converting from $W W$ to AFDW for polychaetes (16\%), prosobranch gastropods $(7.5 \%)$, bivalves $(5.8 \%)$, amphipods $(16 \%)$, and decapods $(16.5 \%)$
\end{abstract}

KEY WORDS: Biomass - Dry weight - Conversion factors Marine invertebrates - Energy flow $\cdot$ Benthos

\section{INTRODUCTION}

Marine research on population dynamics, energy flow, food web interactions, and fishery yields is dependent on estimates of biomass and secondary production, which are normally based on dry weights (Crisp 1975, Warwick 1980, Holme \& McIntyre 1984). Dry weight measurements involve laborious, time-consuming procedures and the destruction of specimens (Holme \& McIntyre 1984). Many researchers calculate mathematical conversion factors from subsamples to facilitate dry weight determinations for a large volume of material (e.g. Ellis 1960, Lie 1968, Trevallion et al. 1970, Eleftheriou \& Basford 1989); this practice allows time for increased sampling effort and more precise taxonomic identifications, which have gained importance with increased interest in biodiversity. The usefulness of specific weight-to-weight conversion factors was recognized by Thorson (1957), Lappalainen \&

•E-mail: anthony.ricciardi@giroq.ulaval.ca
Kangas (1975), and Rumohr et al. (1987), all of whom published compilations of conversion factors for marine macroinvertebrates based primarily on specimens from the Baltic Sea region. Their algorithms have been used for estimating biomass of populations from disparate geographic areas such as northwest Africa (Duineveld et al. 1993) and the Atlantic coast of North America (O'Connor 1972, Croker et al. 1975), because more general and widely-applicable conversion factors are unavailable.

In this paper, we extend the efforts of Baltic Sea researchers by assembling a comprehensive compilation of weight-to-weight conversion factors for marine and estuarine macroinvertebrate taxa, using data obtained from as many species and geographic regions as possible. Our goal is to facilitate general biomass estimates for a broad range of marine benthic studies, especially large-scale spatial and temporal comparisons of secondary production and energy flow (e.g Petersen \& Curtis 1980, Tumbiolo \& Downing 1994) which have previously relied upon very rough approximations of weight-to-weight relationships for standardization of data. 


\section{METHODS}

Weight-to-weight relationships for individual macroinvertebrate taxa were gathered from 42 published and unpublished studies. Specifically, we sought data to convert ash-free dry weight (AFDW) to wet weight (WW), shell-free dry weight (SFDW) to wet weight, and ash-free dry weight to shell-free dry weight (i.e. ash content of dry tissues). In most of these studies, wet weights were determined from fresh material; otherwise, specimens were preserved in formalin (or, less commonly, alcohol) prior to weighing. Wet weights of molluscs and echinoderms include their shells because they are organically connected, while nestling species such as tube-dwelling polychaetes and hermit crabs were weighed without their tubes or shells. For SFDW determinations, the shells and exoskeletons of molluscs and echinoderms were removed manually, or the tissues were dissolved from shells using a dilute $\mathrm{HCl}$ solution. We excluded data from studies that used bleach
$(\mathrm{NaClO})$ to dissolve organic matter, as this treatment causes an overestimation of SFDW (Palmerini \& Bianchi 1994). In general, SFDW was obtained by drying specimens to constant weight in an oven at temperatures of 60 to $110^{\circ} \mathrm{C}$, and AFDW was determined by incineration at 450 to $500^{\circ} \mathrm{C}$ in a muffle furnace.

Data were obtained for $>570$ species. Mean conversion values were calculated for each study that reported more than one value for a given species. Grand arithmetic means were calculated for 28 major taxonomic groups, and $95 \%$ confidence limits were determined using a table of $t$ values (Sokal \& Rohlf 1981). Values from studies cited in more than one review or compilation (e.g. Vinogradov 1953, Thorson 1957) were used only once in our calculations.

Conversion factors based on fresh and preserved (alcohol and formalin) wet weights were compared for major taxa for which sufficient data were available; we chose, a priori, to compare groups for which we obtained at least 4 mean values.

Table 1 Weight-to-weight conversion factors for various taxa. $\mathrm{CI}=95 \%$ confidence interval, $\mathrm{N}=$ number of values, $\mathrm{SPP}=$ number of species, AFDW $=$ ash-free dry weight, $W W=$ wet weight, $D W=$ whole dry weight, SFDW $=$ shell-free dry weight (without shells or exoskeletons)

\begin{tabular}{|c|c|c|c|c|c|c|c|}
\hline Taxon & Conversion & Median \% & Mean \% & $\mathrm{CI}$ & $\mathrm{N}$ & SPP & Sources \\
\hline \multicolumn{8}{|l|}{ Annelida } \\
\hline \multirow[t]{2}{*}{ Oligochaeta } & & 18.0 & 16.7 & $9.2-24.2$ & 3 & $>2$ & 25,34 \\
\hline & $\begin{array}{l}\text { AFDW/DW } \\
\text { AFDW/WW }\end{array}$ & & & & 1 & & 4 \\
\hline \multirow[t]{3}{*}{ Polychaeta, Errantia } & & $\begin{array}{l}16.6 \\
20.0\end{array}$ & $\begin{array}{l}17.1 \\
197\end{array}$ & $\begin{array}{l}15.7-18.5 \\
18.3-21.1\end{array}$ & $\begin{array}{l}48 \\
58\end{array}$ & $\begin{array}{r}>41 \\
44\end{array}$ & $5,12,26,34,38,42$ \\
\hline & & & $\begin{array}{l}19.7 \\
792\end{array}$ & & & $\begin{array}{l}44 \\
57\end{array}$ & $6,12,17,25,26,34,37,39,42$ \\
\hline & AFDW/DW & 83.4 & 79.2 & $76.2-82.2$ & 70 & 57 & $\begin{array}{l}2,4,7,12,13,17,25,26,27,34, \\
37,40,42\end{array}$ \\
\hline \multirow[t]{3}{*}{ Polychaeta, Sedentaria } & AFDW/WW & 14.0 & 15.0 & $13.4-16.6$ & 45 & 42 & $12,26,33,38,42$ \\
\hline & DW/WW & 17.7 & 19.9 & $18.1-21.7$ & 48 & 44 & $6,12,17,25,26,33,37,39,42$ \\
\hline & AFDW/DW & 75.2 & 71.2 & $67.1-75.3$ & 53 & 50 & $4,17,26,27,33,37,40,42$ \\
\hline \multirow[t]{3}{*}{ All polychaetes } & AFDW/WW & 15.6 & 16.0 & $15.0-17.0$ & 93 & $>83$ & \\
\hline & DW/WW & 18.7 & 19.8 & $18.7-20.9$ & 106 & 88 & \\
\hline & AFDW/DW & 79.4 & 75.7 & $73.1-78.3$ & 123 & $>107$ & \\
\hline \multicolumn{8}{|l|}{ Mollusca } \\
\hline \multicolumn{8}{|l|}{ Gastropoda } \\
\hline \multirow[t]{3}{*}{ Prosobranchia } & AFDW/WW & 6.3 & 7.5 & $5.7-9.3$ & 11 & 14 & $12,33,38$ \\
\hline & SFDW/WW & 9.3 & 10.6 & $7.8-13.4$ & 17 & 16 & $5,6,17,33,37,39$ \\
\hline & AFDW/SFDW & 84.9 & 82.6 & $80.2-85.0$ & 54 & 58 & $\begin{array}{l}7,12,17,21,22,27,28,29,33 \\
37,40,42\end{array}$ \\
\hline \multicolumn{8}{|l|}{ Opistobranchia } \\
\hline \multirow[t]{3}{*}{ Shelled taxa } & AFDW/WW & 13.5 & 13.8 & $13.4-14.2$ & 3 & 2 & 38 \\
\hline & SFDW/WW & 8.0 & 7.4 & $4.9-9.9$ & 4 & 4 & $6,14,17,37$ \\
\hline & AFDW/SFDW & 75.0 & 78.3 & $69.0-87.6$ & 7 & 7 & $17,28,37,42$ \\
\hline \multirow[t]{2}{*}{ Non-shelled taxa } & DW/WW & & 25.0 & & 1 & $>2$ & 14 \\
\hline & AFDW/DW & 70.0 & 68.6 & $62.5-74.7$ & 13 & 13 & $27,28,40,42$ \\
\hline Polyplacophora & AFDW/WW & & 27.2 & & 1 & 3 & 5 \\
\hline \multirow[t]{4}{*}{ Bivalvia } & AFDW/WW & 5.5 & 5.8 & $5.2-6.4$ & 66 & 47 & $12,16,18,19,23,24,30,34,38$ \\
\hline & SFDW/WW & 8.6 & 8.7 & $6.9-10.5$ & 36 & 30 & $5,6,9,14,17,34,36,37,39,48$ \\
\hline & AFDW/SFDW & 83.5 & 82.7 & $80.9-84.5$ & 77 & 61 & $\begin{array}{l}1,3,4,7,10,11,13,15,17,18 \\
20,27,30,34,35,36,37,40,42\end{array}$ \\
\hline & AFDW/DW & 16.0 & 14.8 & $13.0-16.6$ & 35 & 19 & $2,13,24,25,26,34,45$ \\
\hline \multirow[t]{3}{*}{ Cephalopoda } & AFDW/WW & 21.7 & 21.4 & $13.6-29.2$ & 5 & 5 & 12,42 \\
\hline & DW/WW & 20.6 & 20.1 & $14.9-25.3$ & 8 & 8 & $12,17,27,42$ \\
\hline & AFDW/DW & 91.8 & 89.2 & $81.3-97.1$ & 10 & 10 & $12,17,27,41,42$ \\
\hline
\end{tabular}


Table 1 (continued)

\begin{tabular}{|c|c|c|c|c|c|c|c|}
\hline Taxon & Conversion & Median \% & Mean \% & $\mathrm{Cl}$ & $\mathrm{N}$ & SPP & Sources \\
\hline \multicolumn{8}{|l|}{ Crustacea } \\
\hline \multirow[t]{3}{*}{ Amphipoda } & AFDW/WW & 16.5 & 16.0 & $14.1-17.4$ & 14 & $>12$ & $5,8,12,34,38,42$ \\
\hline & DWNW & 20.0 & 20.7 & $19.1-22.3$ & 29 & $>21$ & $8,12,14,25,26,34,37,39$ \\
\hline & AFDW/DW & 71.8 & 72.9 & $68.1-77.7$ & 21 & 19 & $4,7,25,26,34,37,40$ \\
\hline \multirow[t]{3}{*}{ Isopoda } & AFDW/WW & & 14.2 & & 1 & 1 & 42 \\
\hline & DW/WW & 20.7 & 20.3 & $17.6-23.0$ & 8 & 5 & $25,34,42$ \\
\hline & AFDW/DW & 65.5 & 63.0 & $57.4-68.6$ & 14 & 12 & $4,25,34,40,42$ \\
\hline \multirow[t]{3}{*}{ Decapoda } & AFDW/WW & 16.5 & 16.5 & $14.6-18.4$ & 17 & 11 & $26,34,38,42$ \\
\hline & DW/WW & 25.4 & 26.2 & $24.0-28.4$ & 48 & 41 & $6,17,26,34,37,39,42$ \\
\hline & AFDW/DW & 69.0 & 66.9 & $62.9-70.9$ & 57 & $>49$ & $6,17,26,27,34,37,40,41,42$ \\
\hline \multirow[t]{3}{*}{ Mysidacea } & AFDW/WW & & 15.5 & & 2 & 2 & 34,42 \\
\hline & DW/WW & 18.0 & 17.5 & $12.2-22.8$ & 5 & 5 & $34,39,42$ \\
\hline & AFDW/DW & 75.5 & 82.4 & $74.4-90.4$ & 6 & 4 & $4,27,34,39,42$ \\
\hline \multirow[t]{3}{*}{ Cumacea } & AFDW/WW & 7.5 & 7.6 & & 4 & 3 & $26,34,38$ \\
\hline & DW/WW & 17.2 & 17.4 & $13.2-21.8$ & 5 & 2 & 26,34 \\
\hline & AFDW/DW & 65.7 & 61.1 & $46.9-75.3$ & 5 & 3 & $26,34,40$ \\
\hline \multirow[t]{3}{*}{ Cirripedia } & AFDW/WW & & 3.9 & & 2 & 2 & 34 \\
\hline & SFDW/WW & 6.5 & 6.6 & $1.8-11.4$ & 4 & 3 & $14,34,37$ \\
\hline & AFDW/SFDW & 79.7 & 78.4 & $66.5-90.3$ & 5 & 4 & $28,37,40$ \\
\hline \multicolumn{8}{|l|}{ Echinodermata } \\
\hline \multirow[t]{3}{*}{ Asteroidea } & AFDW/WW & 9.7 & 11.2 & $7.1-15.3$ & 8 & 4 & $16,38,42$ \\
\hline & AFDW/SFDW & 47.2 & 48.7 & $43.8-53.6$ & 9 & 8 & 27,40 \\
\hline & DW/WW & 28.6 & 32.9 & $24.9-40.9$ & 9 & 7 & $16,17,34$ \\
\hline \multirow[t]{3}{*}{ Ophiuroidea } & $\mathrm{AFDW} / \mathrm{WW}$ & 6.5 & 7.4 & $4.8-10.0$ & 12 & 8 & $20,34,38$ \\
\hline & AFDW/SFDW & 20.4 & 22.9 & $14.3-31.5$ & 5 & 5 & 37,40 \\
\hline & DW/WW & 49.0 & 47.1 & $37.3-56.9$ & 11 & 11 & $12,16,17,34$ \\
\hline Echinoidea & $\mathrm{AFDW} / \mathrm{WW}$ & 2.7 & 3.5 & $1.4-5.6$ & 8 & 6 & $26,33,38$ \\
\hline \multirow{3}{*}{ Holothuroidea } & AFDW/WW & 8.2 & 10.9 & & 3 & 3 & $26,33,42$ \\
\hline & DW/WW & 10.7 & 19.3 & $8.7-29.9$ & 9 & 9 & $6,17,26,33$ \\
\hline & AFDW/DW & 58.8 & 49.6 & $35.0-64.2$ & 13 & 13 & $17,26,27,33,40,42$ \\
\hline \multicolumn{8}{|l|}{ Other groups } \\
\hline \multirow[t]{2}{*}{ Foraminifera } & AFDW/WW & & 1.0 & & 1 & $>3$ & 12 \\
\hline & DW/WW & & 67.0 & & 1 & $>3$ & 12 \\
\hline \multirow{3}{*}{ Porifera (Demospongiae) } & AFDW/WW & 10.5 & 10.7 & $9.3-12.1$ & 9 & 9 & $31,32,42$ \\
\hline & DW/WW & 16.2 & 16.8 & $13.3-20.3$ & 12 & 12 & $31,32,42$ \\
\hline & AFDW/DW & 45.2 & 47.1 & $37.8-56.4$ & 18 & 17 & $27,31,32,40,42$ \\
\hline \multirow[t]{2}{*}{ Actiniaria } & AFDW/WW & 13.3 & 14.3 & $6.0-22.6$ & 4 & 4 & 42 \\
\hline & AFDW/DW & 87.0 & 83.9 & $73.6-94.2$ & 5 & 5 & 40,42 \\
\hline \multirow[t]{3}{*}{ Nemertea } & AFDW/WW & 20.0 & & & 2 & 2 & 34,42 \\
\hline & DW/WW & 21.0 & 20.5 & $14.4-26.6$ & 5 & $>3$ & $12,25,34,42$ \\
\hline & AFDW/DW & 83.2 & 79.9 & $64.0-94.9$ & 4 & $>3$ & $4,34,40,42$ \\
\hline \multirow[t]{3}{*}{ Turbellaria } & AFDW/WW & & 25.2 & & 1 & 1 & 42 \\
\hline & DW/WW & 24.8 & 23.4 & $15.1-31.7$ & 4 & $>3$ & 25,42 \\
\hline & AFDW/DW & & 90.6 & & 1 & 1 & 42 \\
\hline Priapulida & AFDW/WW & & 6.5 & & 1 & 1 & 34 \\
\hline & DW/WW & 8.5 & 9.8 & $5.0-14.7$ & 6 & 2 & 34 \\
\hline & AFDW/DW & & 86.1 & & 1 & 1 & 34 \\
\hline Sipunculida & AFDW/WW & 11.0 & 11.2 & $6.4-16.0$ & 3 & 2 & 26,42 \\
\hline & DW/WW & 17.5 & 17.8 & $5.0-30.6$ & 3 & 2 & 6,42 \\
\hline & AFDW/DW & 66.4 & 64.3 & $41.5-87.1$ & 4 & 3 & $26,40,42$ \\
\hline Ascidiacea & DW/WW & 6.2 & 6.3 & $4.2-8.4$ & 8 & 8 & $17,37,42$ \\
\hline & AFDW/DW & 39.5 & 39.9 & $31.5-48.3$ & 14 & 13 & $17,27,37,42$ \\
\hline Ectoprocta & AFDW/WW & & 7.3 & & 2 & 2 & 42 \\
\hline & AFDW/DW & 39.7 & 40.7 & $28.0-53.4$ & 3 & 3 & 27,40 \\
\hline $\begin{array}{l}\text { Sources: (1) Ansell et al. } 1 \\
\text { (7) Chambers \& Milne } 197 \\
\text { (14) Fradette \& Bourget } 1 \\
\text { (20) Hughes 1970, (21) H } \\
\text { 1975, (26) Lie 1968, (27) N } \\
\text { (32) Reiswig 1981, (33) Ric } \\
\text { 1973, (38) Thorson 1957, ( }\end{array}$ & $\begin{array}{l}\text { (2) Arias \& Dral } \\
\text { ) Collie 1985, (9 } \\
\text { (15) Gardner \& } \\
\text { es 1971a, (22) H } \\
\text { in \& Bamstedt } 1 \\
\text { ds \& Riley 1967, } \\
\text { Tyler 1973, (40) }\end{array}$ & $\begin{array}{l}\text { ke } 1994,(3) \\
9) \text { Dame } 1972 \\
\text { Thomas } 19 \\
\text { Hughes } 1971 \\
\text { 1984, (28) Pa } \\
\text { (34) Rumol } \\
\text { Wacasey \& }\end{array}$ & $\begin{array}{l}\text { Bahr 1976, } \\
\text { (10) Dare } \\
87,(16) \mathrm{Gi} \\
\text { b, (23) Joh } \\
\text { ine 1964, ( } \\
\text { ar et al. } 198 \\
\text { Atkinson } 1\end{array}$ & $\begin{array}{l}\text { 4) Bally } 199 \\
\text { 1976, (11) Da } \\
\text { se } 1966,(17 \\
\text { annessen } 19 \\
\text { 9) Paine } 197 \\
7 \text { (35) Rodho } \\
87, \text { (41) Wiss }\end{array}$ & $\begin{array}{l}\text { 5) E. } \\
\text { E Ed } \\
\text { ilat } \\
\text { (24) } \\
30) P \\
\text { e et }\end{array}$ & $\begin{array}{l}\text { arget } \\
\text { ards } 197 \\
69,(18) \\
\text { osefson } \\
\text { merini } \\
1985,( \\
1973,(4\end{array}$ & $\begin{array}{l}\text { npubl. data, (6) Brawn et al. } 196 \\
\text { 5, (12) Ellis 1960, (13) Evans } 197 \\
\text { Griffiths 1981, (19) Hibbert } 197 \\
\text { 1982, (25) Lappalainen \& Kang } \\
\text { Bianchi 1994, (31) Reiswig } 197 \\
\text { 6) Shafee 1992, (37) Thayer et } \\
\text { 2) Vinogradov } 1953\end{array}$ \\
\hline
\end{tabular}


Table 2. Mean dry weight conversion factors for commercially important species, with $95 \%$ confidence intervals in parentheses Abbreviations and reference numbers are the same as in Table 1

\begin{tabular}{|c|c|c|c|c|}
\hline Taxon & AFDW WW $(\%)$ & SFDW/WW $(\%)$ & DW/WW $(\%)$ & Sources \\
\hline \multicolumn{5}{|l|}{ Mollusca } \\
\hline Buccinum undatum & $10.5(8.3-12.7)$ & 8.0 & 51.5 & $5,34,38$ \\
\hline Cerastoderma edule & 3.6 & & & 19 \\
\hline Choromytilus meridionalis & 5.3 & 6.1 & 72.2 & 18 \\
\hline Clinocardium ciliatum & 3.0 & 8.4 & 74.0 & 6,12 \\
\hline Crassostrea virginica & 1.7 & 2.7 & & 9,37 \\
\hline Mya arenaria & $6.5(2.7-10.3)$ & & 51.9 & $25,26,38$ \\
\hline Mya truncata & 10.5 & & 46.0 & 12,38 \\
\hline Mytilus edulis & $4.6(2.5-6.7)$ & 6.6 & $42.8(27.1-58.5)$ & $5,14,19,25,34,38$ \\
\hline Mytilus galloprovincialis & 7.2 & & & 30 \\
\hline Pecten spp. & 5.0 & 6.0 & & 37,38 \\
\hline Serripes groenlandicus & 11.0 & & 61.0 & 12 \\
\hline Spisula subtruncata & 4.8 & & & 38 \\
\hline \multicolumn{5}{|l|}{ Crustacea } \\
\hline Argis dentata & 18.9 & & 24,4 & 6 \\
\hline Calinectus sapidus & 20.5 & & 29.9 & 37 \\
\hline Cancer pagurus & 20.8 & & 37.4 & 42 \\
\hline Carcinus maenas & $13.8(6.2-21.4)$ & & $25.9(14.4-37.5)$ & 42 \\
\hline Homarus americanus & & & 19.4 & 42 \\
\hline Hyas coarctatus & 22.8 & & 38.1 & 34 \\
\hline Leander adsperus & 19.8 & & & 38 \\
\hline Nephrops norvegicus & 16.7 & & 26.8 & 42 \\
\hline Pandalus montagui & & & 27.9 & 6,39 \\
\hline Peneus spp. & 19.2 & & 25.3 & 37,42 \\
\hline \multicolumn{5}{|l|}{ Echinoidea } \\
\hline Strongylocentrotus droebachiensis & 16.7 & 32.3 & & 6,40 \\
\hline
\end{tabular}

Table 3. Mean $\%$ ash-free dry weight $( \pm 95 \% \mathrm{CI}$ ) for freshly weighed and preserved macroinvertebrates. See Table 1 for sources of data

\begin{tabular}{|lcccc|}
\hline \multirow{2}{*}{ Taxon } & \multicolumn{2}{c}{ AFDW } & \multicolumn{2}{c}{ SFDW/WW } \\
& Fresh, \% & Preserved, \% & Fresh, \% & Preserved, \% \\
\hline Errant polychaetes & $18.3(16.0-20.6)$ & $15.7(14.2-17.2)$ & $21.2(19.6-22.8)$ & $17.6(15.1-20.1)$ \\
Sedentary polychaetes & $17.6(15.1-20.1)$ & $12.1(10.9-13.4)$ & $20.5(18.2-22.8)$ & $19.3(16.2-22.4)$ \\
Prosobranch gastropods & $8.0(5.8-10.2)$ & $6.5(1.4-11.6)$ & & \\
Bivalves & $6.3(5.3-7.3)$ & $5.4(4.6-6.2)$ & $8.1(6.3-9.9)$ & $11.4(5.0-17.8)$ \\
Amphipods & $15.7(13.3-18.2)$ & $16.9(15.6-18.2)$ & $21.8(19.2-24.4)$ & $19.4(17.2-21.6)$ \\
Decapods & & & $26.6(23.1-30.1)$ & $25.7(22.3-29.1)$ \\
\hline
\end{tabular}

\section{RESULTS AND DISCUSSION}

Data are presented for major taxa (Table 1) and species of commercial importance (Table 2). Despite regional and methodological differences between studies, narrow confidence limits surrounded mean conversion factors for polychaetes, prosobranch gastropods, bivalves, amphipods, and decapods (Table 1). AFDW/WW ratios for these taxa had standard errors that were less than $6 \%$ of the mean, suggesting that they would produce useful estimates of biomass. Literature data are scanty for several other common taxa including cnidarians, ectoprocts, ascidians, nemerteans, echinoids, crinoids, and brachiopods; nevertheless, we provided values for these groups when available.

Although preservation in alcohol or formalin may cause substantial changes in weight and tissue composition of invertebrates with time (Thorson 1957, Lappalainen \& Kangas 1975, Dare 1976, Mills et al. 1982, Brey 1986, Dauvin \& Joncourt 1989), mean conversion factors based on fresh vs preserved weights differed only slightly for most major taxa (Table 3), possibly because of short exposure periods prior to weighing. 
Table 4. A comparison of WW-to-AFDW conversion factors for marine benthic macroinvertebrates from various geographic regions. All values are mean $\%$ wet weights

\begin{tabular}{|c|c|c|c|c|c|c|}
\hline & Pacific N. America & Atlantic $N$. America ${ }^{\mathrm{b}}$ & Arctic $^{C}$ & Baltic $^{d}$ & Mediterranean ${ }^{e}$ & This study \\
\hline Polychaetes & 13.3 & 10.5 & $20.0^{f}$ & 13.2 & 11.0 & 16.0 \\
\hline Crustaceans & 15.0 & 13.3 & 15.0 & 14.5 & 15.4 & $14.7^{\mathrm{g}}$ \\
\hline Gastropods $^{\text {h }}$ & & 7.4 & 10.0 & 8.5 & & 7.5 \\
\hline Bivalves & 5.5 & $6.9^{i}$ & 10.0 & 6.9 & 12.5 & 5.8 \\
\hline
\end{tabular}

However, a large weight reduction (about one-third) was evident in sedentary polychaetes. Preservation in formaldehyde/seawater solutions (4 to 10\% formalin) tends to produce much smaller weight changes than in concentrated alcohol (Mills et al. 1982), but long-term storage in both media may cause substantial SFDW or AFDW reductions in annelids and bivalves (Dare 1976, Mills et al. 1982, Brey 1986). The freezing of specimens is therefore recommended over chemical preservation as a method of storage prior to weight determinations (Holme \& McIntyre 1984), although for some delicate specimens (e.g. annelids) taxonomic work may be impaired after thawing. We suggest that estimates of SFDW and AFDW be derived from fresh weights whenever possible.

Other potential sources of variation include seasonal fluctuations in ash content, spawning cycles and condition (e.g. Dare \& Edwards 1975, Chambers \& Milne 1979), sample preparation (Richards \& Richards 1965 , Palmerini \& Bianchi 1994), drying temperature and exposure (Lappalainen \& Kangas 1975, Sisula \& Virtanen 1977). In addition, Rumohr et al. (1987) suggested that lower salinities may lead to higher AFDW/WW ratios in molluscs; to our knowledge, this hypothesis has not been tested. Among different regional studies, variation in conversion factors for bivalves appears to be high relative to other groups (Table 4). This may be because some values were based entirely on fresh weights (Ellis 1960, E. Bourget unpubl.), while others were based on formalin or alcohol wet weights. In contrast, values for crustaceans are remarkably consistent among studies, despite diverse environmental conditions (Table 4).

By averaging over large numbers of studies and species, we have derived mean conversion factors with narrow confidence limits for bivalves, crustaceans, polychaetes, and other major taxa (Table 1). Factors derived from small numbers of values or species (e.g. turbellarians, ectoprocts) should be used with caution. If a high level of precision is required for individual species, it may be preferable for researchers to produce their own conversion factors from subsamples.
Otherwise, our factors should produce useful AFDW estimates for broad spatial and temporal comparisons of zoobenthic communities. Furthermore, they can be used in combination with published weight-to-energy conversions (e.g. Wacasey \& Atkinson 1987, Brey et al. 1988, Dauvin \& Joncourt 1989) to facilitate energy flow studies.

Acknowledgements. We thank $\mathrm{H}$. Rumohr and $\mathrm{T}$. Brey for kindly providing reprints of their work, and H. M. Reiswig for unpublished data on sponges. Financial support in the form of a postdoctoral fellowship to A.R. from the Natural Sciences and Engineering Research Council of Canada is gratefully acknowledged.

\section{LITERATURE CITED}

Ansell AD, Loosmore FA, Lander KF (1964) Studies on the hard-shell clam, Venus mercenaria, in British waters. II. Seasonal cycle in condition and biochemical composition. J Appl Ecol 1:83-95

Arias AM, Drake P (1994) Structure and production of the benthic macroinvertebrate community in a shallow lagoon in the Bay of Cadiz. Mar Ecol Prog Ser 115: 151-167

Bahr LM (1976) Energetic aspects of the intertidal oyster reef community at Sapelo Island, Georgia (USA). Ecology 57: $121-131$

Bally R (1994) Energy and ash contents of sandy beach macrofauna from the West Coast of South Africa. SA J Zool 29 : $82-86$

Brawn VM, Peer DL, Bentley RJ (1968) Caloric content of the standing crop of benthic and epibenthic invertebrates of St. Margaret's Bay, Nova Scotia. J Fish Res Bd Can 25: 1803-1811

Brey T (1986) Formalin and formaldehyde-depot chemicals: effects on dry weight and ash-free dry weight of two marine bivalve species. Meeresforschung 31:52-57

Brey T, Rumohr H, Ankar S (1988) Energy content of macrobenthic invertebrates: general conversion factors from weight to energy. J Exp Mar Biol Ecol 117:271-278

Chambers MR, Milne H (1979) Seasonal variation in the condition of some intertidal invertebrates of the Ythan estuary, Scotland. Estuar Coast Mar Sci 8:411-419

Collie JS (1985) Life history and production of three amphipod species on Georges Bank. Mar Ecol Prog Ser 22: 229-238

Crisp AJ (1975) Secondary productivity in the sea. In: Produc- 
tivity of world ecosystems. National Academy of Sciences, Washington, DC, p 71-89

Croker RA, Hager RP, Scott KJ (1975) Macroinfauna of northern New England marine sand. II. Amphipod-dominated intertidal communities. Can J Zool 53:42-51

Dame RF (1972) Comparison of various allometric relationships in intertidal and subtidal American oysters. Fish Bull 70:1121-1126

Dare PJ (1976) Settlement, growth and production of the mussel, Mytilus edulis L, in Morecambe Bay, England. Fish Invest Ser II 28:1-25

Dare PJ, Edwards DB (1975) Seasonal changes in flesh weight and biochemical composition of mussels (Mytilus edulis L.) in the Conway Estuary, North Wales. J Exp Mar Biol ECol 18:89-97

Dauvin JC, Joncourt M (1989) Energy values of marine benthic invertebrates from the western English Channel. J Mar Biol Assoc UK 69:589-595

Duineveld GCA, de Wilde PAWJ, Berghuis EM, Kok A (1993) The benthic infauna and benthic respiration off the Banc d'Arguin (Mauritania, Northwest Africa). Hydrobiologia 258:107-117

Eleftheriou A, Basford DJ (1989) The macrobenthic infauna of the offshore northern North Sea. J Mar Biol Assoc UK 69: 123-143

Ellis DV (1960) Marine infaunal benthos in Arctic North America. Arct Inst N Am Tech Pap No. 5

Evans RA (1977) The shallow-water soft-bottom benthos in Lindåspollene, western Norway. 2. Estimators of biomass for some macro-infauna species. Sarsia 63:97-111

Fradette P, Bourget E (1980) Ecology of benthic epifauna of the Estuary and Gulf of St. Lawrence: factors influencing their distribution and abundance on buoys. Can J Fish Aquat Sci 37:979-999

Gardner JPA, Thomas MLH (1987) Growth, mortality and production of Mytilus edulis in the Quoddy Region of the Bay of Fundy. Mar Ecol Prog Ser 39:31-36

Giese AC (1966) On the biochemical constitution of some echinoderms. In: Boolootian RA (ed) Physiology of Echinodermata. Interscience Publ, New York, p 757-796

Gilat E (1969) Study of an ecosystem in the coastal waters of the Ligurian Sea. III. Macrobenthic communities. Bull Inst Océanogr Monaco 69:1-76

Griffiths RJ (1981) Population dynamics and growth of the bivalve Choromytilus meridionalis (Kr.) at different tidal levels. Estuar Coast Shelf Sci 12:101-118

Hibbert CJ (1976) Biomass and production of a bivalve community on an intertidal mud-flat. J Exp Mar Biol Ecol 25: $249-261$

Holme NA, McIntyre AD (1984) Methods for the study of marine benthos, 2nd edn. Blackwell Scientific Publ, Oxford

Hughes RN (1970) An energy budget for a tidal flat population of the bivalve Scrobicularia plana (Da Costa). J Anim Ecol 39:357-381

Hughes RN (1971a) Ecological energetics of the keyhole limpet Fissurella barbadensis. J Exp Mar Biol Ecol 59: $167-178$

Hughes RN (1971b) Ecological energetics of Nerita (Archaeogastropoda, Neritacea) populations on Barbados, West Indies. Mar Biol 11:12-22

Johannessen OH (1974) Length and weight relationships and the potential production of the bivalve Venerupis pullastra (Montagu) on a sheltered beach in western Norway. Sarsia 53:41-47

Josefson AB (1982) Regulation of population size, growth and production of a deposit-feeding bivalve: a long-term field study of three deep-water populations off the Swedish coast. J Exp Mar Biol Ecol 59:125-150

Lappalainen A, Kangas P (1975) Littoral benthos of the northern Baltic Sea II. Interrelationships of wet, dry and ashfree dry weights of macrofauna in the Tvarminne area. Int Rev Ges Hydrobiol 60:297-312

Lie $U$ (1968) A quantitative study of the benthic infauna in Puget Sound, Washington, USA in 1963-64. Fiskeridir Skr Ser Havunders 14:229-556

Mills EL, Pittman K, Munroe B (1982) Effect of preservation on the weight of marine benthic invertebrates. Can J Fish Aquat Sci 39:221-224

Norrbin F, Bamstedt U (1984) Energy contents in benthic and planktonic invertebrates of Kosterfjorden, Sweden. A comparison of energetic strategies in marine organism groups. Ophelia 23:47-64

O'Connor JS (1972) The benthic macrofauna of Moriches Bay, New York. Biol Bull (Woods Hole) 142:84-102

Paine RT (1964) Ash and calorie determinations of sponge and opisthobranch tissues. Ecology 45:384-387

Paine RT (1971) Energy flow in a natural population of the herbivorous gastropod Tegula funebralis. Limnol Oceanogr 16:86-98

Palmerini P, Bianchi CN (1994) Biomass measurements and weight-to-weight conversion factors: a comparison of methods applied to the mussel Mytilus galloprovincialis. Mar Biol 120:273-277

Petersen $\mathrm{GH}_{1}$ Curtis MA (1980) Differences in energy flow through major components of subarctic, temperate and tropical marine shelf ecosystems. Dana 1:53-64

Reiswig HM (1973) Population dynamics of three Jamaican Demospongiae. Bull Mar Sci 23:191-226

Reiswig HM (1981) Partial carbon and energy budgets of the bacteriosponge Verongia fistularis (Porifera, Demospongiae) in Barbados. PSZN I: Mar Ecol 2:273-293

Richards NJ, Richards SW (1965) Effect of decalcification procedures on the dry weights of benthic invertebrates. Limnol Oceanogr 10:469-471

Richards SW, Riley GA (1967) The benthic epifauna of Long Island Sound. Bull Bingham Oceanogr Coll 19:89-135

Rodhouse PG, Roden CM, Hensey MP, Ryan TH (1985) Production of mussels, Mytilus edulis in suspended culture and estimates of carbon and nitrogen flow: Killary Harbour, Ireland. J Mar Biol Assoc UK 65:55-68

Rumohr H, Brey T, Ankar S (1987) A compilation of biometric conversion factors for benthic invertebrates of the Baltic Sea. Baltic Mar Biol Publ No. 9:1-56

Shafee MS (1992) Production estimate of a mussel population Perna perna (Born) on the Atlantic coast of Morocco. J Exp Mar Biol Ecol 163:183-197

Sisula H, Virtanen E (1977) Effects of storage on the energy and ash content of biological material. Ann Zool Fenn 14: $119-123$

Sokal RR, Rohlf FJ (1981) Biometry: the principles and practice of statistics in biological research. Freeman Publ, San Francisco

Thayer GW, Schaaf WE, Angelovic JW, LaCroix MW (1973) Caloric measurements of some estuarine organisms. Fish Bull 71:289-296

Thorson G (1957) Bottom communities (sublittoral or shallow shelf). In: Hedgpeth JW (ed) Treatise on marine ecology and paleoecology, Vol I. Geol Soc Am Mem 67:461-534

Trevallion A, Ansell AD, Sivadas P, Narayanan B (1970) A preliminary account of two sandy beaches in South West India. Mar Biol 6:268-279

Tumbiolo ML, Downing JA (1994) An empirical model for the prediction of secondary production in marine benthic 
invertebrate populations. Mar Ecol Prog Ser 114:165-174 Tyler AV (1973) Caloric values of some North Atlantic invertebrates. Mar Biol 19:258--261

Vinogradov AP (1953) The elementary chemical composition of marine organisms. Sears Foundation for Marine Research, New Haven

Wacasey JW, Atkinson EG (1987) Energy values of marine benthic invertebrates from the Canadian Arctic. Mar Ecol

Editorial responsibility: Otto Kinne (Editor),

Oldendorf/Luhe, Germany
Prog Ser 39:243-250

Warwick RM (1980) Population dynamics and secondary production of benthos. In: Tenore KR, Coull BC (eds) Marine benthic dynamics. University of South Carolina Press, Columbia, p 1-24

Wissing TE, Darnell RM, Ibrahim MA, Berner L (1973) Calorific values of marine animals from the Gulf of Mexico. Contrib Mar Sci 17:1-7

Submitted: September 25, 1997; Accepted: December 22, 1997 Proofs received from author(s): February 6, 1998 